\title{
Effect of urea-molasses-mineral-block and azolla (Azolla pinnata) as feed supplements on nutrients utilization and production
}

\author{
Jaswant Kumar $\operatorname{Regar}^{1}$ and Ram Prasad Jat ${ }^{2}$ \\ Received: 11 July 2020 / Accepted: 16 September 2020 / Published online: 27 December 2020 \\ (C) Indian Dairy Association (India) 2020
}

\begin{abstract}
The aim of this research was to evaluate the effect of feed supplements on nutrients utilization and production performance in crossbred cows. Fifteen lactating crossbred cows were divided into three groups based milk yield and body weight and subjected to 3 dietary treatments viz.,:- $\mathrm{T}_{0}$ : Wheat straw and concentrate mixture; $\mathrm{T}_{1}: \mathrm{T}_{0}+\mathrm{UMMB}$; and $\mathrm{T}_{2}: \mathrm{T}_{1}+$ azolla. $\mathrm{UMMB}$ was offered during morning for 30 minutes and fresh Azolla was incorporated@ $1.5 \mathrm{~kg} / \mathrm{animal} / \mathrm{d}$. Average DMI $/ 100 \mathrm{~kg}$ body weight was higher $(\mathrm{P}<0.05)$ in group $\mathrm{T}_{1}$ cows as compared to other groups. Average daily water intake was higher $(\mathrm{P}<0.05)$ in group $\mathrm{T}_{1}$ as compared to $\mathrm{T}_{0}$ and $\mathrm{T}_{2}$ group. Average milk production (litre/ cow) was higher $(\mathrm{P}<0.05)$ in $\mathrm{T}_{1}(7.54)$ as compared to $\mathrm{T}_{2}(7.27)$ and $\mathrm{T}_{0}$ (7.13). It was concluded that UMMB supplementation on wheat straw based diet improved the utilization of nutrients, water intake and milk production in crossbred cows during winter season.
\end{abstract}

Keywords: Crossbred cows, UMMB, Azolla, Nutrients utilization, Milk yield

The productivity of the dairy animals in India is much below the genetic potential. The main constraint for low productivity is the scarcity and fluctuation of the quality and quantity of feed and

\footnotetext{
${ }^{1}$ Department of LPM, S.K.N. College of Agriculture, Jobner, Jaipur, India

${ }^{2}$ Department of LPM, S.K.N. College of Agriculture, Sri Karan Narendra Agriculture University, Jobner-303329, Jaipur, India

Jaswant Kumar Regar ( $\square)$

Department of LPM, S.K.N. College of Agriculture, Sri Karan Narendra Agriculture University, Jobner-303329, Jaipur, Rajasthan, India

Email: jaswantkumarregar468@gmail.com
}

fodder resources. The cereal crop residue and agricultural byproducts are the major forages for dairy animals in Rajasthan. The major factor that limits animal production from these feed resources is nutritional imbalances (Misra et al. 2009), and are insufficient to support nutrients requirements, optimal reproductive performance and sustainable milk production from dairy animals. Many researchers (Misra et al. 2006; Gowda et al. 2015; Lawania and Khadda, 2017) have identified many unconventional feed and fodder resources to maintain the milk production particularly in off season. Supplementation of UMMB and Azolla holds good promise as a feed supplement to dairy animals maintained on low quality feed resources. Misra et al. (2006) has documented the importance of urea molasses mineral block (UMMB) as supplement for livestock. The UMMB lick allows the slow ingestion of urea that efficiently utilized by the rumen microbes. Several experiments have demonstrated the beneficial effects of UMMB supplementation on feed intake, milk production and reproduction of the cows (Kayastha et al. 2012; Misra et al. 2007; Lawania and Khadda, 2017). Azolla has been used as a protein supplement to dairy animals (Meena et al. 2017) and milk yield was increased by 15 to $20 \%$ after feeding azolla in the diet of dairy cows (Gowda et al. 2015). Hence, the present study was conducted to see the effect of UMMB and azolla supplementation on nutrients utilization and milk production in crossbred cows during winter season.

The experiment was conducted for 90 days at the animal farm of LPM department, SKN College of Agriculture, Jobner. Fifteen lactating crossbred (Tharparkar/Sahiwal x Holstein Friesian) cows in early stage of lactation were selected based on body weight and milk yield and randomly divided into three groups as: $T_{0}$ Control: The animals were maintained on conventional diet of wheat straw ad lib. and concentrate mixture, $\mathrm{T}_{1}-\mathrm{T}_{0}+\mathrm{UMMB}$ and $\mathrm{T}_{2}-\mathrm{T}_{0}+$ Azolla, respectively. The animals were dewormed with anthelmintic before the start of actual experiment and were kept individually during experimental period in cattle shed. All cows were fed wheat straw (Triticum aestivum) ad lib. as dry fodder and concentrate mixture (Saras Gold) / as per ICAR, (2013). Animals in group $\mathrm{T}_{1}$ were offered UMMB (Urea molasses mineral bricks) additionally allowing licking for 30 minutes in the morning. Animals of group $\mathrm{T}_{2}$ were supplemented @ $1.5 \mathrm{~kg} / \mathrm{h} / \mathrm{d}$ fresh Azolla in concentrate mixture. The animal had free access to clean and 
fresh drinking water. A digestibility trial of 6 days duration was conducted at the end of experiment. The milk yield was recorded daily in the morning and evening. The samples of feed, fodder and feaces, residue left were collected and analyzed for proximate principles (AOAC, 2005). The experimental data were statistically analyzed (Snedecor and Cochran, 1994). The proximate composition of feed and fodder offered to animals has been given in Table 1

Daily DMI $(\mathrm{kg} / \mathrm{d} \% \mathrm{BW})$ was higher $(\mathrm{P}<0.05)$ in group $\mathrm{T}_{1}$ as compared to group $\mathrm{T}_{0}$ and $\mathrm{T}_{2}$ indicating that wheat straw deficient in nitrogen, energy and minerals, was consumed in higher quantities when these deficiencies were removed by supplementing with UMMB. Similarly higher voluntary consumption of straw vis-à-vis total DM was observed in crossbred calves offered wheat straw and supplemented with UMMB lick (Tiwari et al. 1990; Tripathi et al. 2006; Sahoo et al.
2009; Mohini and Singh, 2010; Sharma et al. 2014; Meel et al. 2015). The average daily voluntary water intake in groups $T_{1} T_{2}$ and $\mathrm{T}_{3}$ was $37.44 \pm 1.18,39.32 \pm 0.71$ and $37.50 \pm 0.35$, respectively (Table-2). The voluntary water intake of cows on treatments $\mathrm{T}_{2}$ was higher than treatments $T_{1}$ and $T_{3}$. The cows in group $T_{2}$ consumed more water due to more DM intake as compared to those in groups $T_{1}$ and $T_{3}$. There was a positive relationship between water intake and milk production and DM content of the diet. Similar finding were reported earlier (Shekhawat and Chaudhary, 2012; Sharma et al. 2014). The CP and DCP intake in the group $\mathrm{T}_{2}$ was more than that in groups $\mathrm{T}_{1}$ and $\mathrm{T}_{3}(\mathrm{P}<0.05)$. The higher $\mathrm{CP}$ and DCP intake in group $\mathrm{T}_{2}$ might be attributed to better utility of nutrients through UMMB. Crude protein intake by the animals was sufficient to meet the requirements (Kumar et al. 2012; Parashuramulu et al. 2013). The feed supplements had significant $(\mathrm{P}<0.05)$ influence on TDN intake by cows. The average daily TDN intake was more $(\mathrm{P}<0.05)$ in $\mathrm{T}_{2}$ as compared to $\mathrm{T}_{1}$ and

Table 1Chemical composition (\% DM basis) of feed and fodders

\begin{tabular}{lllllll}
\hline Ingredient & DM & CP & EE & CF & NFE & Total ash \\
\hline Wheat straw & 90.67 & 4.40 & 1.85 & 32.40 & 48.85 & 12.50 \\
Concentrate mixture & 90.20 & 18.70 & 3.40 & 09.80 & 57.92 & 10.18 \\
UMMB & 82.15 & 31.73 & 4.89 & 05.70 & 34.51 & 23.17 \\
Azolla & 07.80 & 21.37 & 2.80 & 13.20 & 46.42 & 16.21 \\
\hline
\end{tabular}

Table 2 Effect of different feed supplements on nutrient utilization, water intake digestibility of nutrients in crossbred cow during winter

\begin{tabular}{|c|c|c|c|}
\hline \multirow[t]{2}{*}{ Parameter } & \multicolumn{3}{|c|}{ Group } \\
\hline & $\mathrm{T}_{0}$ & $\mathrm{~T}_{1}$ & $\mathrm{~T}_{2}$ \\
\hline Average body weight (kg) & $413.75 \pm 23.493$ & $413.45 \pm 27.101$ & $412.80 \pm 22.434$ \\
\hline \multicolumn{4}{|l|}{ DM Intake (kg/d/animal) } \\
\hline Wheat straw & $7.07^{\mathrm{c}}+0.05$ & $7.64^{\mathrm{a}} \pm 0.05$ & $7.44^{\mathrm{b}} \pm 0.06$ \\
\hline Supplement feed & - & $0.24 \pm 0.00$ & $0.11 \pm 0.00$ \\
\hline Total water intake & $37.44^{\mathrm{c}} \pm 1.18$ & $39.32^{\mathrm{a}} \pm 0.71$ & $37.50^{\mathrm{bc}} \pm 0.35$ \\
\hline Water intake/ kg DMI & $3.31^{\mathrm{c}} \pm 0.025$ & $3.17^{\mathrm{a}} \pm 0.024$ & $3.17^{\mathrm{ab}} \pm 0.02$ \\
\hline \multicolumn{4}{|l|}{ Digestibility of nutrients (\%) } \\
\hline $\mathrm{DM}$ & $69.52^{\mathrm{b}} \pm 1.142$ & $70.16^{\mathrm{a}} \pm 0.200$ & $68.26^{c} \pm 0.996$ \\
\hline $\mathrm{CP}$ & $66.10^{\mathrm{bc}} \pm 2.941$ & $67.09^{\mathrm{a}} \pm 2.020$ & $65.76^{c} \pm 2.291$ \\
\hline \multicolumn{4}{|c|}{ Nutrients intake $(\mathrm{kg} / \mathrm{d} / \mathrm{animal})$} \\
\hline Crude protein intake & $1.131^{\mathrm{b}} \pm 0.084$ & $1.296^{\mathrm{a}} \pm 0.060$ & $0.920^{c} \pm 0.069$ \\
\hline $\mathrm{CPI} / 100 \mathrm{~kg} \mathrm{BW}$ & $0.273^{c} \pm 0.020$ & $0.313^{\mathrm{a}} \pm 0.037$ & $0.285^{\mathrm{bc}} \pm 0.026$ \\
\hline DCP intake & $0.757^{\mathrm{c}} \pm 0.086$ & $0.869^{a} \pm 0.045$ & $0.784^{\mathrm{bc}} \pm 0.062$ \\
\hline DCP intake $/ 100 \mathrm{~kg} \mathrm{BW}$ & $0.183^{c} \pm 0.021$ & $0.210^{\mathrm{a}} \pm 0.018$ & $0.190^{\mathrm{bc}} \pm 0.024$ \\
\hline Daily TDN intake & $7.507^{\mathrm{c}} \pm 0.456$ & $8.095^{\mathrm{a}} \pm 0.211$ & $7.597^{\mathrm{bc}} \pm 0.289$ \\
\hline TDN intake/100 kg BW & $1.81^{\mathrm{c}} \pm 0.07$ & $1.95 \pm 0.18$ & $1.84^{\mathrm{bc}} \pm 0.14$ \\
\hline
\end{tabular}

a,b,c Means having different superscript differ significantly $(\mathrm{P}<0.05)$ 
$\mathrm{T}_{3}$ groups. It was higher in $\mathrm{T}_{2}$ group than other two groups. Improved nutrient utilization with higher feed intake resulted higher TDN intake in UMMB supplemented group. The results are in agreement with the findings of Sihag et al. (2006); Kumar et al. (2012) and Choubey et al. (2015).

Apparent digestibility of DM, CP and NFE were significantly $(\mathrm{P}<0.05)$ higher in $\mathrm{T}_{2}$, as compared to $\mathrm{T}_{2}$ and $\mathrm{T}_{3}$ group due to higher digestibility (Table 2). These results are in close agreement to the findings of (Sihag et al. 2006; Shekhawat and Chaudhary, 2012; Meel et al. 2015). The milk production (L/animal/d) was higher $(\mathrm{P}<0.05)$ in group $\mathrm{T}_{1}\left(7.54^{\mathrm{a}} \pm 1.60\right)$ compared to $\mathrm{T}_{0}\left(7.13^{\mathrm{c}} \pm 1.70\right)$ and $\mathrm{T}_{2}\left(7.27^{\mathrm{bc}} \pm 1.45\right)$. Which may be due to effect of UMMB supplementation (Tripathi et al. 2006; Mohini and Singh, 2010; Mathur et al. 2013; Murthy et al. 2013; Meel et al. 2015).

\section{Conclusion}

Supplementation of UMMB increased nutrient digestibility and milk production in crossbred animals maintained on wheat straw based diet during winter season while inclusion of azolla had no significant effect on the performance of animals.

\section{Acknowledgments}

The authors are thankful to Dr R.C. Kumawat, Dean, and Dr. Mahesh Dutt, Professor, LPM, SKN College of Agriculture, Jobner, Jaipur for providing guidance, infrastructure and necessary support to carry out the research work.

\section{References}

AOAC (2005) Official Methods of Analysis. $18^{\text {th }}$ Edition, Gaitherburg, MD, USA.

Choubey M, Wadhwa M, Bakshi MPS (2015) Evaluation of urea molasses multi-nutrient blocks containing alternate feed resources in buffaloes. Buffalo Bull 34: 1

Gowda NKS, Manegar A, Verma S, Valleesha NC, Maya G, Pal DT, Suresh KP (2015) Azolla (Azolla pinnata) as a green feed supplement for dairy cattle-an on farm study. Anim Nutr Feed Technol 15: 283-287

ICAR (2013) Nutrient requirements of animals-cattle and buffalo (ICARNIANP), New Delhi

Kayastha TB, Dutta S, Roy RK (2012) Impact of supplementation of UMMB licks in the ration of dairy animals. Vetscan 7: 107-110

Kumar DS, Prasad RMV, Kishore KR, Rao ER (2012) Effect of azolla (Azolla pinnata) based concentrate mixture on nutrient utilization in buffalo bulls. Indian J Anim Res 46: 268-271

Lawania P, Khadda BS (2017) Efficacy of urea molasses minerals block on milk production and reproductive performance of zebu cattle under field condition. J Krishi Vigyan 6: 83-87
Mathur GN, Sharma R, Choudhary PC (2013) Use of azolla (Azolla pinnata) as cattle feed. J Krishi Vigyan 2: 73-75

Meel S, Sharma V, Sharma S, Kaushik P (2015) Effect of feeding urea mineral molasses block on milk production traits and economics in Jersey crossbred cows. Int J. Sci Res 4:368-369

Meena GS, Dhaka B, Singh B, Meena RK, (2017) Effect of azolla as feed supplent on milk yield in buffaloes. Int J Curr Microbiol App1 Sci 6: 3490-3494

Misra AK, Rama Rao CA, Subrahmanyam KV, Ramakrishna YS (2009) Improving dairy production in India's rainfed agro ecosystem: Constraints and strategies. Outlook Agric 38: 284-292

Misra AK, Reddy GS, Ramakrishna YS (2006) Participatory on-farm evaluation of urea molasses mineral block as a supplement to crossbred cows for dry season feeding in rainfed agro-ecosystem of India. Livest Res Rural Dev 16: 1-11. www.cipav.org.co/lrrd/1rrd18/2/ misr18024.htm

Misra AK, Subrahmanyam KV, Ramakrishna YS (2007) Effect of urea molasses mineral block supplementation on milk yield in buffaloes: On-farm evaluation under smallholder mixed farming system in semi-arid India. Indian J Anim Sci 77: 94-100

Mohini M, Singh GP (2010) Effect of supplementation of urea molasses mineral block (UMMB) on the milk yield and methane production in lactating cattle on different plane of nutrition. Indian J Anim Nutr 27: 96-102

Murthy TNK, Ashok KM, Thirumalesh T, Umesh BU, Nataraju OR (2013) Effect of partial replacement of azolla for concentrate supplement on lactating crossbred cows. Environ Ecol 31: 415-417

Parashuramulu S, Swain P, Nagalakshmi D (2013) Protein fractionation and in vitro digestibility of Azolla in ruminants. Online J Anim Feed Res 3: 129-132

Sahoo B, Bhushan VC, Kwatra J, Agarwal A (2009) Effect of urea molasses mineral block supplementation on milk production of cows (Bos indicus) in mid hills of Uttarakhand. Anim Nutr Feed Technol 9: 171-178

Sharma M, Singh G, Keshava (2014) Feeding of UMMB licks to dairy animals: A farmers' reactive study. J Krishi Vigyan 2: 39-43

Shekhawat LS, Chaudhary JL (2012) Effect of roof modifications in loose house on intake and utilization of nutrients and milk yield in lactating crossbred cows during winter season. Indian J Dairy Sci 65: 501-507

Sihag ZS, Punia BS, Kishore N (2006) Effect of feeding urea molasses mineral blocks on productive performance of lactating buffaloes. Indian J Anim Nutr 24: 24-26

Snedecor GW, Cochran WG (1994) Statistical Methods. $8^{\text {th }}$ Edn. Lowa state University Press, Ames, lowa, USA

Tiwari SP, Singh UB, Mehra UR (1990) Urea molasses mineral blocks as a supplement: effect on growth and nutrient utilization in buffalo calves. Anim Feed Sci Technol 29: 333-341

Tripathi NK, Pathak SK, Sharma VK (2006) An on-farm evaluation of urea-molasses-mineral brick feeding for the milk production of cattle and buffaloes. Anim. Nutr. Feed Technol 6: 251-255 